\title{
Analisis Kebijakan Peraturan Bupati No. 6 Tahun 2019 Di Lingkungan Kabupaten Tapanuli Tengah Dalam Meningkatkan Kinerja Pegawai Di Kelurahan Sibuluan Indah \\ Policy Analysis Regent Regulation No.6 of 2019 in Improving Employee Performance in Sibuluan Indah Village
}

\author{
Aulia Dhuhri, Isnaini* \& Maksum Syahri Lubis \\ Program Studi Magister Administrasi Publik, Universitas Medan Area, Indonesia \\ Diterima: 09 Juni 2021; Direview: 09 Juni 2021; Disetujui: 15 Desember 2021
}

\begin{abstract}
Abstrak
Tingkat kepuasan masyarakat terhadap pelayanan dari kelurahan masih tergolong rendah terlihat dari banyaknya protes dari masyarakat terhadap kebijakan kelurahan. Keadaan tersebut dapat dilihat dari pelaksanaan pekerjaan yang masih lambat sehingga sebagian besar pekerjaan tidak dapat diselesaikan tepat pada waktu yang ditentukan. Penelitian ini bertujuan untuk mengetahui kebijakan dan faktor kendala apa yang menyebabkan kurang berhasilnya kebijakan Peraturan Bupati No. 6 Tahun 2019 Tentang Pemberian Tambahan Penghasilan Bagi Pegawai Negeri Sipil di Lingkungan Kabupaten Tapanuli Tengah dalam Meningkatkan Kinerja Pegawai di Kelurahan Sibuluan Indah Kecamatan Pandan. Penelitian yang digunakan adalah metode deskriptif, dan teknik analisis data menggunakan deskriptif kualitatif. Hasil penelitian bahwa kebijakan pemberian TPP belum sepenuhnya berhasil meningkatkan kinerja pegawai di Kelurahan Sibuluan Indah Kecamatan Pandan, dengan rekomendasi sebagai berikut: 1) agar pemerintah Kabupaten Tapanuli Tengah perlu melakukan revisi terhadap kebijakan TPP agar lebih merinci tentang unsur-unsur penilaian kinerja, 2) Pejabat penilai perlu menghilangkan pengaruh hubungan pribadi dalam membuat penilaian terhadap kinerja bawahan, dan 3) Pemerintah perlu memperhatikan pembayaran dana TPP dapat dilakukan secara tepat waktu.
\end{abstract}

Kata Kunci: Kebijakan; Peraturan Bupati; Pemberian Tambahan Penghasilan; Kinerja Pegawai.

\section{Abstract}

The level of community satisfaction with services from the kelurahan is still relatively low, as can be seen from the many protests from the community against the kelurahan policy. This situation can be seen from the implementation of the work which is still slow so that most of the work cannot be completed on time. This study aims to determine what policies and constraint factors cause the less successful policy of Regent Regulation no. 6 of 2019 concerning Provision of Additional Income for Civil Servants in Central Tapanuli Regency in Improving Employee Performance in Sibuluan Indah Village, Pandan District. The research used was descriptive method, and the data analysis technique used descriptive qualitative. The results of the study show that the TPP policy has not fully succeeded in improving the performance of employees in Sibuluan Indah Village, Pandan District, with the following recommendations: 1) that the Central Tapanuli Regency government needs to revise the TPP policy so that it is more detailed about the elements of performance appraisal, 2) Officials appraisers need to eliminate the influence of personal relationships in making assessments of the performance of subordinates, and 3) The government needs to pay attention to the payment of TPP funds can be made in a timely manner.

Keywords: Policy; Regent Regulation; Provision of Additional Income; Employee Performance

How to cite: Dhuhri, A. Isnaini \& Lubis, M.S. (2022) Analisis Kebijakan Peraturan Bupati No. 6 Tahun 2019 Di Lingkungan Kabupaten Tapanuli Tengah Dalam Meningkatkan Kinerja Pegawai Di Kelurahan Sibuluan Indah. PERSPEKTIF, 11 (1): 124-130

*Corresponding author: ISSN 2085-0328 (Print) ISSN 2541-5913 (online) 


\section{PENDAHULUAN}

Secara teoritis, banyak faktor yang dapat mempengaruhi atau meningkatkan kinerja pegawai, seperti kepemimpinan, budaya organisasi, dan motivasi. Motivasi kerja adalah dorongan kerja yang timbul pada diri seseorang untuk berperilaku dalam mencapai tujuan yang telah ditentukan (Wahjosumidjo, 2011).

Terdapat anggapan umum bahwa sebagian besar dari kinerja justru dipengaruhi oleh dorongan yang timbul dari dalam diri seseorang untuk melakukan pekerjaan dengan sungguh-sungguh. Keadaan tersebut disebabkan bahwa awal dari dorongan untuk bekerja adalah adanya kebutuhan-kebutuhan hidup yang hanya dapat dipenuhi dengan melakukan pekerjaan secara berhasil. Kebutuhan merupakan daya dorong untuk berperilaku. Pegawai akan berperilaku atau termotivasi dengan baik apabila pekerjaannya dapat memenuhi berbagai kebutuhan seperti gaji atau penghasilan yang layak, suasana kerja yang menyenangkan, kesempatan untuk berkembang, kebutuhan akan pengakuan, kebutuhan berprestasi serta kebutuhan lainnya yang berhubungan dengan peningkatan sosial ekonomi. Semua hal tersebut merupakan faktor-faktor yang dapat membentuk motivasi kerja pegawai.

Oleh karena itu, pemerintah telah berupaya untuk meningkatkan penghasilan pegawai ASN sebagai bentuk motivasi dengan memberikan tambahan penghasilan yang didasarkan pada capaian kinerja pegawai. Hal tersebut dinyatakan dalam Peraturan Pemerintah Nomor 58 Tahun 2005 tentang Pengelolaan Keuangan Daerah pada Pasal 63 ayat 2 yang menyebutkan bahwa "Pemerintah Daerah dapat memberikan tambahan penghasilan kepada pegawai negeri sipil daerah berdasarkan pertimbangan yang obyektif dengan memperhatikan kemampuan keuangan daerah dan memperoleh persetujuan DPRD sesuai dengan ketentuan peraturan perundangan yang berlaku." Sebagai acuan dasar, pemerintah melalui Permendagri telah membuat pedoman pemberian tambahan penghasilan sebagaimana dinyatakan pada Lampiran A, VIII Peraturan Menteri Dalam Negeri Nomor 13 Tahun 2006 yakni penganggaran bagi tambahan penghasilan bagi pegawai di daerah mengacu pada kriteria: a. Tambahan penghasilan berdasarkan beban kerja, b. Tambahan penghasilan berdasarkan tempat bertugas, c. Tambahan penghasilan berdasarkan kondisi kerja, d. Tambahan penghasilan berdasarkan kelangkaan profesi, e. Tambahan penghasilan berdasarkan prestasi kerja.

Sebagai tindak lanjut dari kebijakan pemberian tambahan penghasilan sebagaimana diatur dalam peraturan pemerintah di atas, maka Pemerintahan Kabupaten Tapanuli Tengah telah membuat kebijakan pemberian tambahan penghasilan yang bertujuan untuk meningkatkan kinerja pegawai, sebagaimana dinyatakan dalam Peraturan Bupati No. 6 Tahun 2019 Tentang Pemberian Tambahan Penghasilan Bagi Pegawai Negeri Sipil di Lingkungan Kabupaten Tapanuli Tengah.

Dalam Peraturan Bupati Tapanuli Tengah

No. 6 Tahun 2019 Tentang Pemberian Tambahan Penghasilan Bagi Pegawai Negeri Sipil di Lingkungan Kabupaten Tapanuli Tengah dinyatakan bahwa tambahan penghasilan pegawai yang selanjutnya disebut TPP adalah tambahan penghasilan yang diberikan kepada PNS berdasarkan beban kerja, tempat dan kondisi tugas, kelangkaan profesi dan pertimbangan objektif lainnya. Adapun tujuan pemberian TPP adalah untuk: a. Meningkatkan kualitas pelayanan kepada masyarakat; b. Meningkatkan disiplin PNS, c. Meningkatkan kinerja PNS, d. Meningkatkan keadilan dan kesejahteraan PNS, e. Meningkatkan integritas PNS, dan f. Meningkatkan kreativitas dan inovasi kerja PNS. Aspek penilaian TPP adalah berdasarkan aspek perilaku kerja atau kehadiran kerja dan aspek prestasi kerja, sesuai dengan tingkat jabatannya. Aspek kehadiran didasarkan pada data kehadiran kerja pegawai pada setiap hari, sedangkan aspek prestasi kerja didasarkan pada data laporan hasil kerja pegawai pada setiap hari. a. Untuk jabatan Pelaksana (Fungsional Umum) 100\% (seratus persen) kehadiran, b. Untuk jabatan Pengawas (Eselon IV) $80 \%$ (delapan puluh persen) kehadiran dan $20 \%$ (dua puluh persen) prestasi kerja, c. Untuk jabatan Administrator (Eselon III.b) 70\% (tujuh puluh persen) kehadiran dan 30\% (tiga puluh persen) prestasi kerja, d. Untuk jabatan Administrator (Eselon III.a) 60\% (enam puluh persen) kehadiran dan 40\% (empat puluh persen) prestasi kerja, dan e. Untuk jabatan Pimpinan Tinggi Pratama (Eselon II) 50\% (lima puluh persen) kehadiran dan 50\% (lima puluh 
persen) prestasi kerja. Teori Bernardin (Danim, 2011) menyatakan bahwa kinerja adalah catatan tentang hasil-hasil yang diperoleh dari fungsi-fungsi pekerjaan tertentu atau kegiatan selama kurun waktu tertentu.

Kelurahan Sibuluan Indah merupakan jajaran Pemerintahan Daerah Kabupaten Tapanuli Tengah yang terletak di dalam wilayah administrasi Kecamatan Pandan. Adapun tugas pokoknya adalah memberikan pelayanan kepada masyarakat khususnya pelayanan administrasi kelurahan. Tetapi dari pengamatan penulis bahwa tingkat kepuasan masyarakat terhadap pelayanan dari kelurahan masih tergolong rendah terlihat dari banyaknya protes dari masyarakat terhadap kebijakan kelurahan.

Berdasarkan hasil wawancara di Kantor Kelurahan Sibuluan Indah Kecamatan Pandan diketahui bahwa kinerja pegawai pada instansi tersebut masih tergolong rendah. Keadaan tersebut dapat dilihat dari pelaksanaan pekerjaan yang masih lambat sehingga sebagian besar pekerjaan tidak dapat diselesaikan tepat pada waktu yang ditentukan. Kualitas kerja yang dihasilkan para pegawai juga masih tergolong rendah karena masih kurang sesuai dengan kualitas kerja yang ditetapkan pada standar hasil kerja.

Relatif rendahnya gaji yang diperoleh pegawai, pada umumnya terjadi pada negaranegara berkembang termasuk negara Indonesia, merupakan salah satu hal yang memungkinkan masih belum memadainya pelayanan yang diberikan pegawai kelurahan kepada masyarakat, akibatnya pegawai tidak tenang dalam bekerja, berusaha mencari tambahan pendapatan dalam jam kerja dengan cara antara lain "menjual" jasa pelayanan. Menjual dalam tanda kutip yang penulis cantumkan bukan diartikan sebagai penjualan barang-barang atau benda dalam artian marketing namun arti menjual di sini adalah terjadinya pungli (pungutan liar), yang dilakukan pegawai dalam memberikan pelayanan kepada masyarakat dengan mengatas namakan jasa. Kemungkinan relatif rendahnya gaji pegawai kelurahan menyebabkan terjadinya "penjualan" jasa pelayanan, sehingga mengakibatkan tinggi atau mahalnya biaya pelayanan yang dibebankan oleh pegawai kepada masyarakat pemakai jasanya. Masyarakat yang membutuhkan jasa pegawai kelurahan mau atau tidak terpaksa membayar. Wajar apabila pelayanan yang diberikan pegawai/aparat kelurahan diharapkan dapat dilaksanakan secara baik, efektif dan efisien dan dapat dirasakan oleh seluruh masyarakat. Namun pada kenyataannya pelayanan yang diberikan aparat kelurahan kepada masyarakat belum memadai dan dirasakan kurang memberikan pelayanan secara efektif dan efisien, hal itu berdasarkan pengamatan yang telah dilakukan penulis, yakni dapat dilihat dari prosedur pelayanan yang masih lambat waktu penyelesain yang relatif lama, sehingga karakter dari masyarakat terlihat dimana untuk memperlancar urusannya maka masyarakat yang membutuhkan pelayanan dari kelurahan tersebut rela mengeluarkan sejumlah uang, dalam hal ini khususnya dalam pelayanan pembuatan Kartu Tanda Penduduk (KTP), pembuatan Kartu Keluarga (KK), dan pembuatan Surat/Akta Tanah, sehingga tidak memenuhi tuntutan tingkatan perkembangan penyelenggaraan pemerintah yang seharusnya diterima masyarakat.

Oleh karena itu, penulis tertarik membuat penelitian dalam bentuk tulisan dengan judul: Analisis Kebijakan Peraturan Bupati No. 6 Tahun 2019 Tentang Pemberian Tambahan Penghasilan Bagi Pegawai Negeri Sipil di Lingkungan Kabupaten Tapanuli Tengah dalam Meningkatkan Kinerja Pegawai di Kelurahan Sibuluan Indah Kecamatan Pandan.

\section{METODE PENELITIAN}

Penelitian ini menggunakan metode deskriptif kualitatif. Dimana peneliti mendeskripsikan apa yang dilihat, didengar, dirasakan dan ditanyakan. Penelitian dilakukan pada Kantor Kelurahan Sibuluan Indah Kecamatan Pandan Kabupaten Tapanuli Tengah. Penelitian di kelurahaan ini dipilih karena di kelurahan ini masih terdapat beberapa kelemahan dalam bidang kinerja pegawai.

Informan penelitian dipilih secara purposive sampling. Informan penelitian didasarkan pada pertimbangan bahwa informan penelitian dapat memberikan informasi dan yang selengkap-lengkapnya dan relevan dengan tujuan penelitian. Informan yang digunakan dalam penelitian ini sebanyak 3 orang, adalah Informan kunci yaitu Reyaldo Samosir, SAP selaku Sekretaris Lurah, informan utama yaitu Suriati selaku Kepala Seksi 
Pemerintahan dan informan tambahan yaitu Firjatullah, S.STP selaku Kepala Seksi Kesejahteraan Sosial.

Teknik pengumpulan data dalam penelitian ini adalah penelitian kepustakaan dan penelitian lapangan dengan menggunakan teknik wawancara dan observasi.

Teknik analisis data: data reduction (reduksi data), data display (penyajian data), dan conclusion drawing (verification dan penarikan kesimpulan).

\section{HASIL DAN PEMBAHASAN}

\section{Letak Geografis Kabupaten Tapanuli Tengah}

Letak geografis Kabupaten Tapanuli Tengah berada pada ketinggian 0-1.266 m diatas permukaan laut dan terletak pada koordinat $1^{\circ} 11^{\prime} 00^{\prime \prime}-2^{\circ} 22^{\prime} 0^{\prime \prime}$ LU dan $98^{\circ} 07^{\prime}$ $98^{\circ} 12^{\prime}$ BT dengan batas-batas wilayah padasebelah utara berbatas dengan Provinsi Aceh, sebelah selatan berbatas dengan Kabupaten Tapanuli Selatan, sebelah timur berbatas dengan Kabupaten Tapanuli Utara danKabupaten Humbang Hasundutan dan Pakpak Bharat di sebelah barat berbatasan dengan Sibolga dan Samudera Indonesia.

Kelurahan dan Desa berdasarkan Kecamatan di Kabupaten Tapanuli Tengah, yaitu sebagai berikut: Sebagian besar desa di Kabupaten Tapanuli Tengah adalah masih dalam kategori Daerah Tertinggal, yaitu : 7 desa di Kecamatan Manduamas, 5 desa di Kecamatan Sirandorung, 10 desa di Kecamatan Andam Dewi, 1 desa di Kecamatan Barus Utara, 4 desa di Kecamatan Barus, 4 desa di Kecamatan Sosorgadong, 7 desa di Kecamatan Pasaribu Tobing, 2 desa di Kecamatan Sorkam Barat, 6 desa di Kecamatan Sorkam, 6 desa di Kecamatan Kolang, 4 desa di Kecamatan Tapian Nauli, 1 kelurahan dan 2 desa di Kecamatan Sitahuis, 2 kelurahan dan 1 desa di Kecamatan Sarudik, 7 desa di Kecamatan Tukka, 5 desa di Kecamatan Badiri, 3 desa di Kecamatan Pinangsori, 1 desa di Kecamatan Lumut, 4 desa di Kecamatan Sibabangun, dan 3 desa di Kecamatan Sukabangun.

\section{Kebijakan Peraturan Bupati No. 6 Tahun 2019}

Quality (Kualitas Kerja). Kualitas hasil kerja mengukur sejauh mana pegawai dapat menghasilkan pekerjaan sesuai dengan standar kualitas yang ditetapkan. Kemampuan dalam melaksanakan tugas bukan hanya dibutuhkan seorang pegawai yang profesional. Hal tersebut dapat dilihat dari keterampilan dan pengalaman pegawai yang semakin baik dan tentunya dalam hal ini juga ditunjang oleh kualitas sumber daya manusia yang dimilikinya maka kinerja pegawai dapat diperoleh semaksimal mungkin.

Setelah adanya TPP maka pegawai menjadi lebih teliti dalam bekerja serta memperhatikan agar hasil pekerjaan dan tempat bekerja tetap dalam kondisi rapih. Setiap pegawai menjadi lebih memperhatikan prosedur kerja yang telah ditetapkan sehingga hasil pekerjaan jarang bermasalah. Artinya bahwa kualitas pekerjaan menjadi lebih baik sehingga pelayanan kepada masyarakat juga menjadi lebih baik. Dengan demikian dapat disimpulkan bahwa dengan pemberian TPP kepada pegawai telah mendorong pegawai untuk menghasilkan pekerjaan dengan kualitas yang lebih sesuai dengan standar yang ditetapkan, sehingga sangat mendukung terhadap peningkatan kinerja pegawai di Kelurahan Sibuluan Indah Kecamatan Pandan.

Quantity (Kuantitas Hasil Kerja). Kuantitas hasil kerja mengukur sejauh mana pegawai dapat menyelesaikan volume pekerjaan yang dibebankan kepadanya. Kemampuan pegawai yang tinggi untuk menyelesaikan volume pekerjaannya yaitu jumlah yang harus diselesaikan atau dicapai berkaitan dengan jumlah keluaran yang dihasilkan akan meningkatkan kinerja pegawai tersebut.

Pegawai secara rutin berupaya mengejar target hasil kerja, dimana tujuan pegawai dalam bekerja telah ditetapkan sebagaimana telah dinyatakan dalam SKP. Setiap pegawai juga menyadari dengan baik bahwa pencapaian SKP merupakan syarat utama dalam pemberian TPP. Dengan demikian dapat disimpulkan bahwa pemberian TPP telah mendorong pegawai untuk lebih mampu mencapai hasil kerja sesuai SKP sehingga sangat mendukung terhadap peningkatan kinerja pegawai di Kelurahan Sibuluan Indah Kecamatan Pandan.

\section{Timelines (Ketepatan Waktu).}

Ketepatan waktu mengukur sejauhmana pegawai dapat memanfaatkan seluruh waktu kerja untuk menangani pekerjaan yang dibebankan kepadanya. Kemampuan pegawai yang semakin tinggi dalam menyelesaikan 
pekerjaan dengan tepat waktu maka kinerja yang dihasilkan semakin tinggi.

Pegawai telah meningkatkan disiplinannya, dengan lebih patuh terhadap aturan waktu kerja sebagaimana telah diatur dalam Perbup TPP. Namun demikian bahwa tingkat disiplin yang dimaksud masih tetap perlu lebih ditingkatkan, karena pegawai masih mangkir dari pekerjaan jika ada urusan keluarga, yang didukung dengan kurang sikap pimpinan yang lebih toleran. Dengan demikian dapat disimpulkan bahwa pemberian TPP telah mendorong pegawai untuk meningkatkan disiplin terhadap waktu jam kerja sehingga sangat mendukung terhadap peningkatan kinerja pegawai di Kelurahan Sibuluan Indah Kecamatan Pandan.

Cost-effectiveness (efektifitas sumber daya). Efektifitas sumber daya mengukur sejauhmana pegawai dapat memanfaatkan sumber daya yang tersedia dengan menghindari terjadinya pemborosan. Kemampuan pegawai memanfaatkan sumber daya yang tersedia dengan sebaik-baiknya maka kinerja yang diperoleh juga semakin tinggi.

Upaya untuk menghindari agar tidak ada bahan terbuang masih tergolong kurang baik. Hal ini menyebabkan terjadinya pemborosan dalam bekerja, seperti pemborosan perlengkapan kerja dan juga pembororan sumber daya energy. Hal ini merupakan dampak dari upaya untuk mempercepat pelaksanaan pekerjaan dengan mempertahankan kualitas kerja. Perbub TPP juga tidak mensyaratkan pemborosan menjadi factor penilaian kinerja. Dengan demikian dapat disimpulkan bahwa pemberian TPP tidak mendorong pegawai untuk menghindari pemborosan sehingga kurang mendukung terhadap peningkatan kinerja pegawai di Kelurahan Sibuluan Indah Kecamatan Pandan.

Need for Supervision (Kebutuhan Pengawasan). Kebutuhan pengawasan mengukur sejauhmana pegawai dapat melaksanakan pekerjaan tanpa perlu harus mendapat pengawasan yang ketat. Kemampuan pegawai bekerja yang tinggi tercapai tanpa harus diawasi dengan ketat menunjukkan kinerjanya juga akan meningkat.

Pegawai belum mampu secara mandiri dalam mengatasi masalah yang timbul dalam pekerjaan. Kendala yang ditemukan dalam proses pelaksanaan pekerjaan masih lebih dominan menunggu arahan dari atasan, sehingga dapat memperlambat pelaksanaan pelayanan masyarakat. Unsur mengatasi kendala dalam bekerja juga tidak menjadi faktor penilaian dari atasan untuk memperoleh TPP.

\section{Interpersonal Impact (Hubungan}

Kerjasama). Hubungan kerjasama mengukur sejauhmana peawai memiliki keinginan untuk menciptakan iklim yang sehat untuk bekerja serta memelihara hubungan kerjasama yang baik. Kemampuan pegawai membina kerjasama yang baik dengan rekan kerja maka kinerja juga semakin meningkat.

Pimpinan organisasi cukup memperhatikan untuk menciptakan kondisi yang baik dalam bekerja bagi pegawai, yaitu dengan berperan sebagai mediator yang baik dalam memelihara hubungan antar pegawai. Dengan terciptanya suasana yang harmonis dalam lingkungan kepegawaian, maka pergesekan pegawai juga terhindar dari pergesekan social yang berpotensi mengganggu pelaksanaan pekerjaan. Dengan demikian dapat disimpulkan bahwa pemberian TPP telah mendorong pimpinan untuk menciptakan iklim kerja yang sehat, sehingga sangat mendukung terhadap peningkatan kinerja pegawai di Kelurahan Sibuluan Indah Kecamatan Pandan.

\section{Faktor Kendala}

Perwal TPP kurang membuat rincian dengan jelas tentang penilaian aspek kinerja. Kebijakan TPP lebih dominan mengatur tentang jam kerja sedangkan aturan tentang perilaku kerja tidak ada. Unsur pengaturan yang tidak jelas khususnya dapat dilihat dari tidak adanya penilaian terhadap upaya menghindari pemborosan, upaya mengatasi masalah yang timbul dalam pekerjaan, serta tidak adanya penilaian terhadap unsur kerjasama dalam penilaian. Kebijakan TPP lebih terfokus dalam melakukan penilaian dari segi aspek kehadiran bekerja, keterlambatan, apel pagi, dan hal lainnya yang berkaitan dengan kedisiplinan waktu. Hal ini menyebabkan pegawai lebih mengutamakan kehadiran, sementara perilaku pada saat bekerja agar dapat bekerja secara efektif dan efisien tidak ada, padahal menurut Mathis dan Jackson (2012) bahwa kualitas kerja adalah kerapian, ketelitian, dan keterkaitan hasil dengan tidak mengabaikan volume pekerjaan 
Untuk mengatasi kendala tersebut maka sebaiknya dilakukan revisi terhadap kebijakan TPP, agar pengaturan terhadap unsur-unsur penilaian menjadi lebih terperinci dan tidak hanya dominan mengatur tentang disiplin waktu kerja.

Pejabat penilai (atasan) tidak mampu mengendalikan pandangan hubungan pribadi dalam melakukan penilaian hasil kerja bawahan. Menurut informan bahwa pegawai yang berupaya membuat hubungan pribadi dengan mencari perhatian cenderung mendapat nilai yang bagus dari atasan walaupun hasil kerjanya biasa-biasa saja, sehingga nilai yang diperoleh dapat menyamai nilai kerja pegawai yang hasil kerjanya benarbenar bagus.

Pegawai di lingkungan Kelurahan Sibuhuan Indah sering membuat laporan secara berlebihan, dalam arti pegawai melaporkan hasil kerja yang belum selesai dalam laporan kinerja sebagai telah rampung. Hasil wawancara tersebut menunjukkan terdapat juga beberapa pegawai yang secara sengaja menambah hasil kerja yang dilaporkan, dengan tujuan untuk memperoleh nilai kinerja yang lebih tinggi. Dengan demikian dapat disimpulkan bahwa pegawai masih kurang jujur dalam membuat laporan kinerja, sehingga kurang mendukung dalam upaya peningkatan kinerja dan disiplin pegawai.

\section{SIMPULAN}

Kebijakan Pemberian TPP sebagaimana diatur dalam Peraturan Bupati No. 6 Tahun 2019 Tentang Pemberian Tambahan Penghasilan Bagi Pegawai Negeri Sipil di Lingkungan Kabupaten Tapanuli Tengah belum sepenuhnya berhasil meningkatkan kinerja pegawai di Kelurahan Sibuluan Indah Kecamatan Pandan. Indikator kinerja menurut teori Benardin yang belum berhasil adalah costeffectiveness (efektifitas sumber daya) yaitu upaya untuk menghindari agar tidak ada bahan terbuang masih tergolong kurang baik, menyebabkan terjadinya pemborosan dalam bekerja, seperti pemborosan perlengkapan kerja dan juga pembororan sumber daya energi. Need for Supervision (kebutuhan pengawasan) yaitu pegawai belum mampu secara mandiri dalam mengatasi masalah yang timbul dalam pekerjaan, dalam proses pelaksanaan pekerjaan masih lebih dominan menunggu arahan dari atasan, sehingga dapat memperlambat pelaksanaan pelayanan masyarakat. Sedangkan indikator yang sudah tergolong baik adalah quality (kualitas), quantity (kuantitas), timeliness (ketepatan), dan interpersonal impact (hubungan kerjasama).

Adapun faktor kendala yang menyebabkan tidak berhasilnya kebijakan TPP meningkatkan kinerja pegawai adalah: Kebijakan TPP lebih dominan mengatur tentang disiplin waktu kerja dan kurang mengatur tentang unsur penilaian kinerja seperti pemborosan terhadap penggunaan sumber daya dan prakarsa dalam mengatasi masalah dalam pekerjaan. Kebijakan TPP lebih terfokus dalam melakukan penilaian dari segi aspek kehadiran bekerja, keterlambatan, apel bagi, dan hal lainnya yang berkaitan dengan kedisiplinan waktu. Pada sisi lain pejabat penilai kurang objektif melakukan penilaian laporan hasil kerja karena dipengaruhi oleh hubungan pribadi, sementara terdapat juga beberapa pegawai yang secara sengaja menambah hasil kerja yang dilaporkan, dengan tujuan untuk memperoleh nilai kinerja yang lebih tinggi. Pembayaran dana TPP juga kadang tidak dapat dilakukan secara tepat waktu, karena dana yang diperlukan belum tersedia atau belum mencukupi.

\section{DAFTAR PUSTAKA}

Anastacia, D., Nasution, I., \& Suharyanto, A. (2021). Peranan Motivasi dalam Meningkatkan Kinerja Pegawai Berbasis Kebutuhan. Strukturasi: Jurnal Ilmiah Magister Administrasi Publik, 3(2), 176-184. doi:https://doi.org/10.31289/strukturasi.v3 i2.747

Andika, M, dan Tarigan, U. (2013). Evaluasi Kinerja Pemerintah Desa Bandar Tengah Kecamatan Bandar Khalifah Kabupaten Serdang Bedagai, JPPUMA: Jurnal Ilmu Pemerintahan dan Sosial Politik UMA (Journal of Governance and Political UMA), 1 (2): 98-111.

Bagia, I.W. (2015). Perilaku Organisasi. Yogyakarta: Graha Ilmu.

Danim, S. (2011). Kinerja staf dan Organisasi. Bandung: Pustaka Setia.

http://imamalfie.blogspot.com/2013/12/selamatdatang-era-baru-sumber-daya.html, diakses pada tanggal 3 Agustus 2020.

Ketike, R., Harahap, R., \& Siregar, N. (2021). Analisis Kinerja Dinas Pengelolaan Keuangan Daerah Di Bidang Pendapatan Pada Kabupaten Gayo Lues. Strukturasi: Jurnal Ilmiah Magister Administrasi Publik, 3(1), 99-117. 
doi:https://doi.org/10.31289/strukturasi.v3 i1.726

Mathis, R.L., dan Jackson, J.H. (2012). Manajemen Sumber Daya Manusia.Jakarta: Salemba Empat.

Muslim, N. dan Irwan N., (2014). Kinerja Aparat Desa Dalam Penyelenggaraan Pemerintahan Di Desa Pantai Labu Pekan, JPPUMA: Jurnal Ilmu Pemerintahan dan Sosial Politik UMA (Journal of Governance and Political UMA), 2 (2): 114-124

Novita, D., Kadir, A., \& Siregar, N. (2020). Analisis Kinerja Inspektorat Daerah Dalam Melakukan Fungsi Pengawasan (Studi Pada Inspektorat Kota Langsa). Strukturasi: Jurnal Ilmiah Magister Administrasi Publik, 2(2), 116-128.

doi:https://doi.org/10.31289/strukturasi.v2 i2.52

Peraturan Bupati No. 6 Tahun 2019 No. 6 Tahun 2019 Tentang Pemberian Tambahan Penghasilan Bagi Pegawai Negeri Sipil di Lingkungan Kabupaten Tapanuli Tengah.

Peraturan Menteri PAN dan RB No. 1 Tahun 2020 tentang Pedoman Analisis Jabatan dan Analisis Beban Kerja

Peraturan Menteri PAN dan RB No. 34 Tahun 2011 tentang Pedoman Evaluasi Jabatan Pegawai Negeri.

Peraturan Pemerintah No. 11 Tahun 2017 Tentang Manajemen Pegawai Negeri Sipil.

Peraturan Pemerintah Nomor 58 Tahun 2005 tentang Pengelolaan Keuangan Daerah.

Simbolon, A.H., dan Walid M.S., (2015). Evaluasi Kinerja Badan Permusyawaratan Desa dalam
Penyelenggaraan Pemerintahan Desa, JPPUMA: Jurnal Ilmu Pemerintahan dan Sosial Politik UMA (Journal of Governance and Political UMA), 1 (1): 143-159.

Sinaga, M.C.D.M. dan Yusnah M., (2015). Pelaksanaan PP RI No.19/2008 Sebagai Acuan Kinerja Camat pada Aspek Pemerintahan dan Pendidikan, JPPUMA: Jurnal Ilmu Pemerintahan dan Sosial Politik UMA (Journal of Governance and Political UMA), 3 (1): 36-48.

Sirait, N., Warjio, W., Harahap, D., \& Kadir, A. (2019). Analisis Kinerja Aparatur Sipil Negara dalam hal Disiplin Kerja di Kantor Kecamatan Tanjungbalai Utara Kota Tanjungbalai. Strukturasi: Jurnal Ilmiah Magister Administrasi Publik, 1(2), 165-175

Sitanggang, M.D., dan Suadi H., (2014). Persepsi Masyarakat Terhadap Kinerja Camat Dalam Meningkatkan Mutu Pendidikan, JPPUMA: Jurnal Ilmu Pemerintahan dan Sosial Politik UMA (Journal of Governance and Political UMA), 2 (1): 58-77

Suhendar, A. (2021). Pengaruh Persepsi tentang Perubahan Struktur Organisasi terhadap Kinerja Pegawai pada Direktorat Jenderal EBTKE Kementerian ESDM. Journal of Education, Humaniora and Social Sciences (JEHSS), 4(1), 546-552. doi:https://doi.org/10.34007/jehss.v4i1.61 0

Undang-Undang No. 5 Tahun 2014 Tentang Aparatur Sipil Negara.

Wahjosumidjo. (2011). Kepemimpinan. Jakarta: Raja GrafindoPersada. 